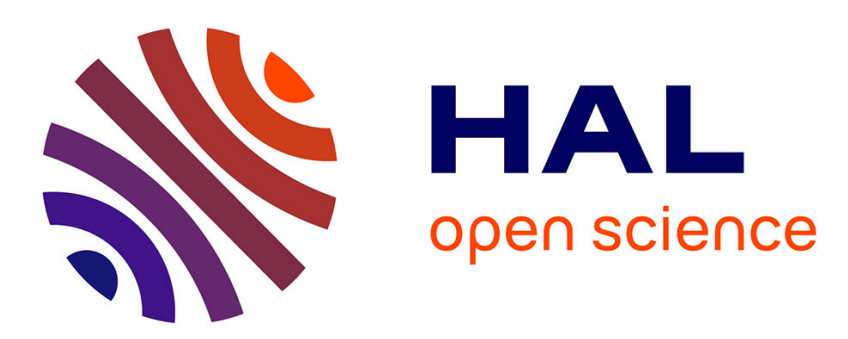

\title{
Collected customs duties: the level of taxation on imports applied by the US and the EU
}

\author{
Jacques Gallezot, Vincent Aussilloux
}

\section{To cite this version:}

Jacques Gallezot, Vincent Aussilloux. Collected customs duties: the level of taxation on imports applied by the US and the EU. The World Economy, 2008, 31 (9), pp.1208-1225. 10.1111/j.14679701.2008.01119.x . hal-01172873

\section{HAL Id: hal-01172873 \\ https://hal.science/hal-01172873}

Submitted on 30 May 2020

HAL is a multi-disciplinary open access archive for the deposit and dissemination of scientific research documents, whether they are published or not. The documents may come from teaching and research institutions in France or abroad, or from public or private research centers.
L'archive ouverte pluridisciplinaire HAL, est destinée au dépôt et à la diffusion de documents scientifiques de niveau recherche, publiés ou non, émanant des établissements d'enseignement et de recherche français ou étrangers, des laboratoires publics ou privés. 


\title{
The level of taxation on imports applied by the US and the EU
}

\author{
Jacques Gallezot* and Vincent Aussilloux**
}

\section{INTRODUCTION}

The aim of the Doha Development Agenda is to pursue the liberalisation of trade policy among World Trade Organisation (WTO) Members. It is the occasion for fierce discussions on finding a multilateral consensus over additional reductions of trade barriers. However, discussions centre on "bound" customs duties notified to the WTO which comply with the Most Favoured Nation (MFN) clause. These are «ceiling» customs duties, defined by "a product that countries have committed not to increase". In many respects this type of duties can differ from the duties actually applied, and even more so from actual market access conditions when other types of trade barriers or special arrangements come into play. Hence, the bound tariff does not correspond to the right measure of taxation of imports.

\footnotetext{
* JACQUES GALLEZOT, Director of Research at INRA and associate researcher at CEPII, UMR d'Economie Publique, INRA- INAPG

** VINCENT AUSSILLOUX, European Commission, DG-Trade

The findings, interpretations and conclusions expressed in this paper are entirely those of the authors, and do not necessarily represent the view of their institutions. The authors thank the anonymous referees for helpful comments.
} 
Instead of trying to measure the real level of import taxation from a legal point of view by computing all preferential agreements and specific exemptions that exist, this paper proceeds by computing the real amount of duties effectively paid to get foreign goods into the US and EU markets. It means taking into account the customs duty that is actually applied in all its dimensions (exceptions, suspensions, preferential duties, quotas, MFN duties, etc.) and emphasizing what is actually collected as tax, which constitutes a tax revenue.

\section{MERITS AND LIMITATIONS OF MEASURING COLLECTED DUTIES}

Duties notified to the WTO constitute a commitment undertaken by Members to not exceed a level of taxation which must also comply with the MFN clause. In fact, the MFN duty actually applied can be far lower, as is the case for a great number of developing countries which have notified high ceiling duties to the WTO. This difference provides further flexibility in multilateral negotiations insofar as the negotiated reductions only concern notified duties (Bchir et al., 2005). As a result, the difference between the notified multilateral duty, and the duty actually applied, dilutes the actual ambition of a great market opening.

A customs duty's form of expression is often complex, the simplest being a tax percentage of the good's value (ad-valorem duty). However, this tax is also often expressed in specific duties (tax in monetary amount per unit of measure of the good, for example 30 euros per $100 \mathrm{~kg}$ ), or by a combination of the two. This situation makes comparative analyses or operations of aggregation very delicate. As a result, attempts to reduce tariff peaks, which constitute one of the objectives of current multilateral negotiations, have run into difficulty. This debate has notably driven the WTO Members' work throughout the course of 2005 in preparation of the Hong Kong Ministerial meetings and reach an agreement on a common method for translating all duties into "ad-valorem equivalents" (AVE). Although rather technical, this is an 
important result of the negotiations. Furthermore, this transformation of specific or complex duties into AVEs is a methodological advance that allows the simple classification of goods in different rate bands. Nonetheless, the duty applied upon a product's entry into the market continues to be expressed as a specific or complex tax. ${ }^{1}$ In addition to this difficulty of translating duties into AVEs, there is the fact that certain tariff measures concern only a limited volume of imports. Such quotas are usually associated with non-tariff barriers (certificates, licences, conditions of allocation, etc.). This is the reason why the system of quotas is sometimes used only partially by the exporters due to administrative costs entailed.

Concerning the openness of certain markets, the reality differs even more from the level of taxation discussed at the WTO if the numerous preferential agreements are taken into account. Indeed, the last few years have seen the number of such agreements become widespread between WTO Members and more particularly between the developed and developing countries. These preferential agreements nevertheless need to comply with WTO rules, in particular Article XXIV of the General Agreement on Tariffs and Trade (GATT). These bilateral or regional free trade agreements constitute one of the main reasons why the actual degree of openness of certain markets can depart from the level computed when looking only at WTO bound tariffs. Under a preferential regime, however, it must be proved that the imported products actually originate from countries that have a preferential agreement, as defined by the rules of origin of the agreement. This is the reason why exporters, faced with this constraint of

\footnotetext{
${ }^{1}$ A duty expressed in amount per unit of measure will give a very different AVE estimate depending on the product's price. The AVE will be higher if this price is low. Given the great variability of prices for a same product, depending on the origin and sometimes the period, the annual AVE can only be very rough.
} 
having to comply with rules of origin, sometimes prefer to give up this advantage (Gallezot and Bureau, 2004; Brenton and Manchin, 2002) and opt for the MFN tariff. Analyzing collected duties has the advantage of integrating simultaneously and in a homogenous and comprehensible manner (in monetary amounts) all the dimensions of a tariff regime, however complex including: the level and structure of ad valorem duties and of specific duties, seasonal variations in agricultural duties, anti-dumping duties, preferential trade arrangements, the utilisation rate of trade preferences, eventual additional elements, etc. Thus, relating the collected duty to the value of imports enables to estimate a more comprehensive AVE of the actual rate of applied duty by integrating all the applied duty's components.

Nonetheless, collected duties measure the overall effects of taxation without translating perfectly the whole level of protection. As the level of imports depends on the level of protection, the existence of tariff peaks may, for example, explain why there are no imports in such a case, resulting in the lack of collected duties. This problem of endogenous taxation and levels of trade is not a precise limit specific to the analysis of collected duties. This bias can be found in most models simulating the trade impact resulting from a modification of taxes under prohibitive tariffs. More generally, the difficulty lies in translating the levels of market protection from taxes, particularly when it comes to getting an aggregated estimate of the level of duties of a country or of an economic sector. In this case, the simple arithmetic mean of duties is tantamount to considering that all products have the same importance, while the imports-weighted average takes into account the importing country's preferences and the geographic orientation of exports. None of the methods are without inconveniences, in other words, without bias. 


\section{COMPUTATION OF EU COLLECTED DUTIES}

With regards to taxation, EU Member States retain their national prerogatives. This is the reason why there exists no detailed European statistics on collected duties beyond the global amount transmitted to the Union's budget. ${ }^{2}$ The operation carried out in this study relies, therefore, on an evaluation of levies based on the declaratory administrative files of companies when clearing customs (Single Administrative Document, SAD) and on customs regulations addressed at the most detailed level (TARIC).

In order to undertake this evaluation, it is necessary to mobilise the concerned administrative files and to rectify those tax declarations that do not comply with regulations (see Appendix). This operation, relatively cumbersome with regards to the processing of information, benefits from the experience already acquired through previous research papers on estimating the utilisation rate of trade preferences (Gallezot, 2003; Gallezot and Bureau, 2005). Analysing the conditions of preference utilisation is important as third countries, in addition to multilateral market access conditions (MFN duties or quotas) to the EU or US markets, benefit from preferential agreements that may or may not be used.

In sum, duties effectively levied are directly linked to the import regime under which each good enters the EU market (MFN, bilateral or unilateral preference). In addition, the real collected duty depends on some specific measures such as tariff suspensions and MFN or preferential in- and out-quota duties.

The analysis of such complex import scheme shows that 73.4 per cent of EU imports enter under the MFN regime contributing to 85.7 per cent of total custom receipts. 26.6

\footnotetext{
${ }^{2}$ No detailed customs tax statistics are forwarded by the Member States to the Directorate General Budget, and neither to the Directorate General Trade or Directorate General Taxud of the European Commission.
} 
per cent benefit from a preferential access to the EU market, contributing to 14.3 per cent to total custom receipts (Table 1). Almost half of overall EU imports (49.2 per cent) enter under zero MFN tariff.

Table 1: EU structure of collected duties in 2003

\begin{tabular}{|c|c|c|c|c|c|}
\hline \multirow{2}{*}{$\begin{array}{l}\text { Tariff } \\
\text { Measure }\end{array}$} & \multicolumn{2}{|l|}{ Import } & \multicolumn{2}{|c|}{ Collected } & \multirow{2}{*}{$\begin{array}{c}\text { AVE } \\
\% \\
{[2] /[1]}\end{array}$} \\
\hline & $\begin{array}{c}1000 € \\
{[1]}\end{array}$ & $\%$ & $\begin{array}{c}1000 € \\
{[2]}\end{array}$ & $\%$ & \\
\hline MFN (0\% tax) & 459126568 & 49.2 & 0 & 0.0 & 0 \\
\hline MFN dutiable & 184006307 & 19.7 & 11730174 & 81.7 & 6.4 \\
\hline MFN suspensions & 33145977 & 3.6 & 5570 & 0.0 & 0.0 \\
\hline MFN quotas & 8749957 & 0.9 & 565970 & 3.9 & 6.5 \\
\hline Preferential duties & 244225121 & 26.2 & 1857953 & 12.9 & 0.8 \\
\hline Preferential quotas & 4092456 & 0.4 & 193380 & 1.3 & 4.7 \\
\hline Total & 933346386 & 100 & 14353047 & 100 & 1.5 \\
\hline
\end{tabular}

Sources: SAD (Eurostat); TARIC (DG Taxud)

\section{OVERALL RATE OF LEVY OF THE EU AND THE US}

In 2003 the final accounts of the EU budget (at 15) show a custom revenue of 11,594 million euros for customs duties. ${ }^{3}$ However, a 25 per cent levy by Member States, which corresponds to "collection costs", reduces at the source the total amount of this EU budget contribution (11,594 million euros). When taking into account this fact, duties collected by the EU in 2003 amounted to 14,492 million euros. As a result, relating the amount of collected duties to the EU's overall imports, which in 2003 amounted to 933,346 millions euros, ${ }^{4}$ gives a corresponding tax rate of 1.5 per cent.

3 Sources: (http://www.europa.eu.int/int/eur-lex/budget/data/D2003_v1) Europa Eur-Lex, Budget 2003, Title 1, own resources. 2003 Budget makes a distinction between collected custom duties of 10,714 million euros and the amount of 880 million euros levied on imports of agricultural products that fall under a Common Market Organization including sugar and isoglucose. For their part, customs duties come from the application of the common customs tariffs on the customs value of goods imported from third countries.

${ }^{4}$ These imports take into account trade exchanges that fall under outward processing activities (statistical procedure 3) to the tune of 15,048 million euros. The tax base for these trade 
For the US, the statistics on collected duties published by the USITC (2004) show an amount of 18,253 millions dollars, for an amount of total imports of 1,226,915 million dollars. ${ }^{5}$ The US tax rate on imports amounts therefore to 1.5 per cent and is thus equivalent to the EU's tax rate.

Table 2: Levels of EU and US collected duties in 2003

\begin{tabular}{|c|c|c|c|c|c|c|c|c|c|c|}
\hline & \multicolumn{5}{|c|}{ EU } & \multicolumn{5}{|c|}{ USA } \\
\hline Bands of & Number & Import & Collected & AVE & MFN & Number & Import & Collected & AVE & MFN \\
\hline MFN duties & lines & $1,000 €$ & $1,000 €$ & $\%$ & $\%$ & lines & $\$ 1,000$ & $\$ 1,000$ & $\%$ & $\%$ \\
\hline$\%$ & Tariffs & [1] & [2] & {$[2] /[1]$} & & Tariffs & [1] & [2] & {$[2] /[1]$} & \\
\hline & & & & & & & & & & \\
\hline 0 & 2,214 & $459,126,568$ & 0 & 0.0 & 0 & 3,117 & $564,109,796$ & 0 & 0.0 & 0 \\
\hline $0.1-4.9 \%$ & 3,721 & $238,025,958$ & $2,618,284$ & 1.1 & 2.5 & 3,487 & $468,632,681$ & $6,010,791$ & 1.3 & 2.8 \\
\hline $5-15 \%$ & 3,271 & $211,202,847$ & $8,393,935$ & 4.0 & 8.3 & 2,733 & $125,101,168$ & $4,939,436$ & 3.9 & 8.3 \\
\hline$>15 \%$ & 936 & $24,991,013$ & $3,340,828$ & 13.4 & 32.3 & 637 & $69,164,094$ & $7,346,788$ & 10.6 & 27.8 \\
\hline Total & 10,142 & $933,346,386$ & $14,353,047$ & 1.5 & 6.6 & 9,974 & $1,227,007,740$ & $18,297,015$ & 1.5 & 5 \\
\hline
\end{tabular}

The MFN duty is an arithmetic mean of nominal rates

Sources: SAD (Eurostat); TARIC (DG Taxud); USITC

The processing of collected duties, based on budgetary data as highlighted in the introduction, shows that the customs duties' rate of levy on imports is equivalent for the US and the EU (Table 2). Overall, it can also be noted that in the American and European schemes the rates of collected duties are well below the level of MFN duties. This situation can be explained by taking into account preferential regimes and all suspensive measures.

By considering the collected duties according to the different MFN tax thresholds, it appears that there is little difference between the EU and US rates of levies with

exchanges only concerns the re-imported added value, following processing activities undertaken outside the EU (Eurostat, 2003). An added value flat rate of 30 per cent has been considered here.

${ }^{5}$ See: http://dataweb.usitc.gov/. 
regards to MFN duties that are below 15 per cent (Table 2). However, for the highest MFN duties (above 15 per cent) the EU's rate of levy is higher on the whole (13.4 per cent compared to 10.6 per cent for the US). For these imported products subjected to high duties, the average corresponding MFN duties are 32 per cent for the EU and 27.8 per cent for the US. Thus, for products that are highly taxed on the multilateral level there are preferential agreements that lead, for the EU and US, to distinctly lower applied rates of duties (about 50 per cent less than the MFN duty). It must be remembered that the higher the duties, the lower the imports, and this even leads in instances of prohibitive duties to an absence of imports and therefore of collected duties.

If the AVE computed here puts the US and the EU on an equal footing, such a figure, as noted by Gresser (2002a), offers little interest. ${ }^{6}$ The essential point here being how these taxes are levied on the exports of partner countries, and which products are the most affected by such a tax level.

\section{COMPARATIVE LEVEL OF TAXATION VIS-A-VIS LDCS AND}

\section{DEVELOPING COUNTRIES}

The rate of collected duties in 2003, according to countries' development category, reveals that US taxes on the poorest countries' exports are higher than those of the EU. Thus, the rate of duties actually applied by the US on Least Developed Countries (LDCs) and developing countries is 5.3 per cent and 1.9 per cent respectively, compared to only 1.7 per cent and 1.8 per cent for the EU (Table 3 ). ${ }^{7}$ Setting aside those products which enter MFN free of duty, the rate of taxation applied by the US with regards to LDCs is 15 per cent, whereas in the EU's case it is only 3.7 per cent.

\footnotetext{
${ }^{6}$ See also Bourcieu (2004).

${ }^{7}$ For the sake of clarity, the group of developing countries excludes the Least Developed Countries in all the text and tables.
} 
The consequences of the «Everything But Arms»(EBA) European initiative are almost certainly related to this situation. Nevertheless, the EU's rate of applied duties with regards to LDCs is still higher than zero. This can be explained by remaining quotas regarding sugar, rice or bananas which are progressively dismantled vis-à-vis LDCs with an end date in 2009. This may also be related to the current rules of origin ${ }^{8}$. However, as shown by Curran et al. (2006), utilisation rates of preferences accorded to developing countries are high - generally above 90 percent. ${ }^{9}$ This indicates that criticisms of the EU's preferences due to its 'restrictive' rules of origin are misplaced. ${ }^{10}$ Where there does seem to be an issue with utilisation is in clothing, but difficulties seem to be concentrated in non-knitted clothing (HS 62). Knitted clothing (HS61) and other made up textiles (HS63) have relatively high rates of utilisation. It is likely that the double transformation origin rule (requiring clothing to be made up from yarn) may be an issue in this underutilisation in HS62. ${ }^{11}$ The need to take into account the development needs of beneficiaries will be one of the issues considered in the revision of the rules of origin currently being considered within the EU (CEC, 2005).

Table 3: EU and US collected duties according to countries' development category

\footnotetext{
${ }^{8}$ Gallezot and Bureau (2005).

${ }^{9}$ See also OECD (2005).

${ }^{10} \mathrm{Cf}$. for example Brenton and Manchin (2002).

${ }^{11}$ See Candau and Jean (2005).
} 


\begin{tabular}{|c|c|c|c|c|c|c|c|c|c|c|}
\hline & \multicolumn{5}{|c|}{ UE } & \multicolumn{5}{|c|}{ US } \\
\hline \multirow{2}{*}{\begin{tabular}{|l|} 
Countries \\
Categories
\end{tabular}} & \multirow[t]{2}{*}{ Import } & \multirow[t]{2}{*}{ Dutiable } & \multirow[t]{2}{*}{ Collected } & \multicolumn{2}{|c|}{ AVE } & \multirow[t]{2}{*}{ Import } & \multirow[t]{2}{*}{ Dutiable } & \multirow[t]{2}{*}{ Collected } & \multicolumn{2}{|c|}{ AVE } \\
\hline & & & & applied & dutiable & & & & applied & dutiable \\
\hline year 2003 & $1,000 €$ & $1,000 €$ & $1,000 €$ & $\%$ & $\%$ & $\$ 1,000$ & $\$ 1,000$ & $\$ 1,000$ & $\%$ & $\%$ \\
\hline & [1] & [2] & [3] & {$[3] /[1]$} & {$[3] /[2]$} & [1] & [2] & [3] & {$[3] /[1]$} & [3]/[2] \\
\hline Developed & $443,440,146$ & $247,528,231$ & $5,691,887$ & 1.3 & 2.3 & $613,255,383$ & $196,664,543$ & $6,173,933$ & 1.0 & 3.1 \\
\hline Developing & $477,016,468$ & $205,699,886$ & $8,440,062$ & 1.8 & 4.1 & $602,696,680$ & $186,175,514$ & $11,535,892$ & 1.9 & 6.2 \\
\hline LDCs & $12,889,772$ & $5,898,451$ & 221,099 & 1.7 & 3.7 & $11,055,682$ & $3,921,895$ & 587,191 & 5.3 & 15.0 \\
\hline Total & 933346387 & 459126568 & 14353047 & 1.5 & 3.1 & 1227007745 & 386761952 & 18297016 & 1.5 & 4.7 \\
\hline
\end{tabular}

Sources: SAD (Eurostat); TARIC (DG Taxud); USITC

In general, the rate of taxation applied by the EU is much more balanced with regards to the development categories of countries than that of the US. As a result, for dutiable products (excluding products entering duty free) the differences between rates of levies by import origin are smaller in the case of the EU (two points compared to twelve for the US) and penalize less developing countries and LDCs. By considering the MFN duties that are higher than five per cent, it can also be noted that duties actually applied by the EU correspond to an even bigger preferential margin for LDC exports (Table 4).

The average rate of MFN duties applicable on LDC exports to the EU is 12.2 per cent, whereas the rate of duties actually applied is 3.4 per cent, and conversely the poorest countries' exports to the US face a rate of levy (12.5 per cent) which is close to the average rate of MFN duties (13.9 per cent).

Table 4: EU and US collected duties for the most highly taxed products

\begin{tabular}{|c|c|c|c|c|c|c|c|c|}
\hline MFN $>5 \%$ & \multicolumn{4}{|c|}{ UE } & \multicolumn{4}{|c|}{ US } \\
\hline Countries & Import & Collected & \multicolumn{2}{|c|}{ AVE (\%) } & Import & Collected & \multicolumn{2}{|c|}{ AVE (\%) } \\
\hline Categories & $1,000 €$ & $1,000 €$ & Collected & MFN & $\$ 1,000$ & $\$ 1,000$ & Collected & MFN \\
\hline Developed & $113,107,306$ & $4,216,241$ & 3.7 & 10.7 & $68,083,155$ & $2,390,565$ & 3.5 & 10.9 \\
\hline Developing & $116,557,047$ & $7,296,853$ & 6.3 & 11 & $121,498,531$ & $9,311,185$ & 7.7 & 11.7 \\
\hline LDCs & $6,529,507$ & 219,054 & 3.4 & 12.2 & $4,683,577$ & 584,475 & 12.5 & 13.9 \\
\hline Total & 236193860 & 12620486 & 5.3 & 10.9 & 194265263 & 12286225 & 6.3 & 11.4 \\
\hline
\end{tabular}

Most of EU and US duty receipts are levied on imports coming from Asian countries

(Table 5). The first two contributors to the EU and the US import tax receipts are China 
and Japan. Other Asian countries rank high in the list of both the EU and the US. From the point of view of the importance of collected duties, the first 50 countries represent approximately 95 per cent of the total tax revenue of the US ( 96.3 per cent) and the EU (94.8 per cent), and cover almost 90 per cent of US (90.4 per cent) and EU (84.9 per cent) imports.

Beyond this relative concentration of exporting countries, the table highlights more precisely the countries whose exports are the most taxed. In the US case, the stylized facts already emphasized by Gresser (2002b) can be noted, particularly with the situation of Bangladesh (LDC) which is taxed as heavily as France even though it exports 15 times less than France to the US market $\left(56^{\text {th }}\right.$ importer and $15^{\text {th }}$ contributor to the American tax revenue). This situation reflects a particularly high tax rate which exists in the American system in relation to developing countries such as Cambodia (15.6 per cent), Vietnam (12.2 per cent), Sri Lanka (13.9 per cent), Pakistan (10.6 per cent), or Nicaragua ( 8 per cent). Although it concerns a smaller number of developing countries and does not affect LDCs, this situation also exists in the European system, for example in relation to Sri Lanka, Ecuador or Panama. ${ }^{12}$ American and European real taxation with regards to developing countries can therefore be explained, notably, by the differentiated level of taxation according to the type of product exported.

\footnotetext{
${ }^{12}$ The case of Burma being, as for the US, linked to this LDC's exclusion from the advantages of preferential regimes due to its situation with regards to human rights.
} 
Table 5: EU and US collected duties for the first 50 contributing countries in 2003

\begin{tabular}{|c|c|c|c|c|c|c|c|c|c|c|c|c|c|}
\hline EUImport & Import & Collected & Impor & Collec & GNI & Rate & USA Import & Import & Collected & Import & Follect & GNI & Rate \\
\hline From Countries & $1,000 €$ & $1,000 €$ & Rank & Rank & Rank & $\%$ & From Countries & $\$ 1,000$ & $\$ 1,000$ & Rank & Rank & Rank & \\
\hline 2003 & [1] & [2] & & & & [2У[1] & 2003 & [1] & [2] & & & & {$[2 \mathrm{Y}[1]$} \\
\hline China & $94,357,400$ & $2,572,532$ & 2 & 1 & 152 & 2.7 & China & $140,245,728$ & $3,693,426$ & 2 & 1 & 152 & 2.6 \\
\hline Japan & $61,678,220$ & $1,907,786$ & 3 & 2 & 6 & 3.1 & Japan & $118,386,640$ & $2,101,662$ & 4 & 2 & 6 & 1.8 \\
\hline U.S.A. & $129,002,376$ & $1,606,651$ & 1 & 3 & 5 & 1.2 & Germany & $66,433,064$ & $1,164,262$ & 5 & 3 & 17 & 1.8 \\
\hline South Korea & $22,840,978$ & 664,663 & 11 & 4 & 56 & 2.9 & South Korea & $36,858,500$ & 939,426 & 7 & 4 & 56 & 2.5 \\
\hline Brazil & $17,055,994$ & 469,426 & 13 & 5 & 108 & 2.8 & Taiw an & $31,325,400$ & 806,331 & 8 & 5 & 36 & 2.6 \\
\hline India & $12,890,658$ & 435,304 & 18 & 6 & 184 & 3.4 & Italy & $24,048,484$ & 771,527 & 12 & 6 & 26 & 3.2 \\
\hline Thailand & $10,704,373$ & 420,301 & 23 & 7 & 121 & 3.9 & Hong Kong & $8,707,221$ & 751,527 & 26 & 7 & 11 & 8.6 \\
\hline Norw ay & $40,112,884$ & 322,559 & 6 & 8 & 2 & 0.8 & Indonesia & $8,612,448$ & 483,739 & 27 & 8 & 160 & 5.6 \\
\hline Taiw an & $19,814,018$ & 306,001 & 12 & 9 & 36 & 1.5 & India & $12,516,236$ & 465,912 & 19 & 9 & 184 & 3.7 \\
\hline Indonesia & $9,532,938$ & 304,981 & 25 & 10 & 160 & 3.2 & Vietnam & $3,586,652$ & 437,523 & 44 & 10 & 188 & 12.2 \\
\hline New Zealand & $2,785,218$ & 289,042 & 48 & 11 & 49 & 10.4 & Thailand & $14,167,777$ & 435,320 & 17 & 11 & 121 & 3.1 \\
\hline Hong Kong & $8,989,504$ & 282,723 & 26 & 12 & 11 & 3.1 & United Kingdom & $42,364,440$ & 432,934 & 6 & 12 & 10 & 1.0 \\
\hline Turkey & $23,580,168$ & 264,383 & 10 & 13 & 112 & 1.1 & Philippines & $9,972,674$ & 393,146 & 25 & 13 & 148 & 3.9 \\
\hline Argentina & $5,737,190$ & 229,849 & 36 & 14 & 87 & 4.0 & France & $28,862,378$ & 320,942 & 9 & 14 & 20 & 1.1 \\
\hline Sw itzerland & $52,800,836$ & 220,831 & 4 & 15 & 3 & 0.4 & Bangladesh & $1,990,248$ & 302,299 & 56 & 15 & 196 & 15.2 \\
\hline Singapore & $13,333,786$ & 217,656 & 17 & 16 & 21 & 1.6 & Pakistan & $2,530,064$ & 267,031 & 50 & 16 & 182 & 10.6 \\
\hline V ietnam & $4,453,482$ & 215,098 & 38 & 17 & 188 & 4.8 & Turkey & $3,773,818$ & 264,836 & 39 & 17 & 112 & 7.0 \\
\hline Ecuador & $1,100,772$ & 197,388 & 65 & 18 & 134 & 17.9 & SriLanka & $1,781,666$ & 248,081 & 59 & 18 & 157 & 13.9 \\
\hline Costa Rica & $2,371,402$ & 191,925 & 52 & 19 & 89 & 8.1 & Brazil & $16,470,262$ & 247,253 & 15 & 19 & 108 & 1.5 \\
\hline Poland & $31,048,392$ & 171,001 & 7 & 20 & 80 & 0.6 & Macao & $1,347,561$ & 236,675 & 61 & 20 & 30 & 17.6 \\
\hline Malaysia & $13,623,932$ & 167,367 & 15 & 21 & 99 & 1.2 & Malaysia & $25,307,758$ & 229,344 & 11 & 21 & 99 & 0.9 \\
\hline Colombia & $2,241,874$ & 159,290 & 53 & 22 & 125 & 7.1 & Guatemala & $2,931,464$ & 203,773 & 48 & 22 & 128 & 7.0 \\
\hline Russian Federation & $42,482,092$ & 156,956 & 5 & 23 & 116 & 0.4 & Cambodia & $1,261,987$ & 196,379 & 63 & 23 & 204 & 15.6 \\
\hline Hungary & $25,587,896$ & 131,882 & 9 & 24 & 77 & 0.5 & Mexico & $136,581,888$ & 193,405 & 3 & 24 & 74 & 0.1 \\
\hline Canada & $13,432,773$ & 127,063 & 16 & 25 & 18 & 0.9 & Canada & $222,322,704$ & 170,167 & 1 & 25 & 18 & 0.1 \\
\hline Slovakia & $12,221,152$ & 126,841 & 19 & 26 & 88 & 1.0 & Spain & $6,387,246$ & 152,004 & 29 & 26 & 44 & 2.4 \\
\hline South Africa & $14,119,485$ & 121,926 & 14 & 27 & 111 & 0.9 & Sw itzerland & $10,465,252$ & 145,649 & 22 & 27 & 3 & 1.4 \\
\hline Bangladesh & $3,564,276$ & 120,808 & 40 & 28 & 196 & 3.4 & Sw eden & $11,134,839$ & 138,853 & 20 & 28 & 9 & 1.2 \\
\hline Czech rep. & $29,359,486$ & 100,377 & 8 & 29 & 75 & 0.3 & Belgique-luxembourg & $10,365,258$ & 120,304 & 23 & 29 & 15 & 1.2 \\
\hline Australia & $8,160,346$ & 99,520 & 27 & 30 & 23 & 1.2 & Netherland & $10,954,076$ & 110,438 & 21 & 30 & 14 & 1.0 \\
\hline Pakistan & $2,921,231$ & 80,015 & 47 & 31 & 182 & 2.7 & Australia & $6,376,734$ & 107,920 & 30 & 31 & 23 & 1.7 \\
\hline Mauritius & $1,062,164$ & 78,088 & 66 & 32 & 95 & 7.4 & Russian Federation & $8,129,880$ & 102,729 & 28 & 32 & 116 & 1.3 \\
\hline Panama & 458,733 & 77,604 & 93 & 33 & 91 & 16.9 & El Salvador & $2,002,999$ & 83,127 & 55 & 33 & 117 & 4.2 \\
\hline Philippines & $6,227,932$ & 68,998 & 31 & 34 & 148 & 1.1 & Honduras & $3,210,374$ & 82,269 & 46 & 34 & 154 & 2.6 \\
\hline Sri Lanka & $1,323,570$ & 66,837 & 62 & 35 & 157 & 5.0 & Singapore & $14,251,659$ & 79,339 & 16 & 35 & 21 & 0.6 \\
\hline Chile & $4,813,678$ & 64,508 & 37 & 36 & 86 & 1.3 & Egypt & $1,124,626$ & 75,078 & 64 & 36 & 135 & 6.7 \\
\hline Macao & 681,941 & 61,258 & 78 & 37 & 30 & 9.0 & AUSTRIA & $4,312,971$ & 65,107 & 36 & 37 & 13 & 1.5 \\
\hline Cameroon & $1,710,330$ & 50,214 & 57 & 38 & 175 & 2.9 & New Zealand & $2,288,300$ & 64,683 & 53 & 38 & 49 & 2.8 \\
\hline Iceland & $1,603,449$ & 49,524 & 59 & 39 & 8 & 3.1 & Saudi Arabia & $17,103,616$ & 62,709 & 13 & 39 & 68 & 0.4 \\
\hline Romania & $11,076,273$ & 46,485 & 21 & 40 & 124 & 0.4 & Nicaragua & 699,629 & 55,646 & 69 & 40 & 164 & 8.0 \\
\hline Mexico & $5,752,274$ & 40,603 & 35 & 41 & 74 & 0.7 & Dominican Republic & $4,315,864$ & 54,888 & 35 & 41 & 114 & 1.3 \\
\hline Ukraine & $3,147,346$ & 37,682 & 43 & 42 & 163 & 1.2 & Portugal & $1,865,887$ & 52,006 & 58 & 42 & 61 & 2.8 \\
\hline United A rab Emirates & $3,496,730$ & 37,186 & 41 & 43 & 48 & 1.1 & United A rab Emirates & $1,121,572$ & 49,536 & 65 & 43 & 48 & 4.4 \\
\hline Guyana & 187,860 & 35,827 & 119 & 44 & 156 & 19.1 & Colombia & $6,312,807$ & 43,368 & 31 & 44 & 125 & 0.7 \\
\hline Croatia & $2,547,038$ & 35,596 & 50 & 45 & 81 & 1.4 & Argentina & $3,015,224$ & 41,385 & 47 & 45 & 87 & 1.4 \\
\hline Morocco & $6,030,968$ & 34,869 & 33 & 46 & 143 & 0.6 & Denmark & $3,653,212$ & 39,002 & 42 & 46 & 7 & 1.1 \\
\hline Uruguay & 563,266 & 34,207 & 82 & 47 & 84 & 6.1 & Myanmar & 256,415 & 38,463 & 95 & 47 & 200 & 15.0 \\
\hline Bulgaria & $3,662,547$ & 33,618 & 39 & 48 & 127 & 0.9 & Brunei & 334,320 & 35,420 & 89 & 48 & 59 & 10.6 \\
\hline Tunisia & $5,971,370$ & 32,755 & 34 & 49 & 122 & 0.5 & Venezuela & $16,596,961$ & 34,057 & 14 & 49 & 93 & 0.2 \\
\hline Myanmar & 379,420 & 32,365 & 96 & 50 & 200 & 8.5 & Bahrain & 378,090 & 30,053 & 86 & 50 & 55 & 7.9 \\
\hline Total Selection [1] & $792,602,021$ & $13,600,369$ & & & & & Total Selection [1] & $1,109,044,873$ & $17,620,953$ & & & & \\
\hline Total EU2003 [2] & $933,349,386$ & $14,352,672$ & & & & & Total USA 2003 [2] & $1,227,007,745$ & $18,297,016$ & & & & \\
\hline Selection in \% ([1][2]) & 84.9 & 94.8 & & & & & Selection in \% ([1 $][2])$ & 90.4 & 96.3 & & & & \\
\hline
\end{tabular}

Countries selection in grey for GNI rank $>100$ and rate of collected duties over imports $>5$ per cent

Sources : SAD (Eurostat); TARIC (DG Taxud); USITC ; UN Statistics Division 


\section{COMPARATIVE LEVEL OF TAXATION BY SECTOR}

The first 40 groups of products (HS 2), from the point of view of collected duties, represent 94 per cent of EU and 96 per cent of US customs duties revenues (Table 6). Although the order of the first four products that contribute to the American or European tax revenue differs slightly, they are the same: vehicles other than railways (HS 87), articles of apparel and clothing accessories (knitted and others, HS 62 and HS 61), video and sound electric and electronic machinery and equipment (HS 85).

However, products on the European or American markets are affected differently by the intensity of the applied duties' level of taxes. Except for the dairy sector which remains protected in both markets, the other sectors differ more greatly. For the US market, the sectors that are the most highly taxed upon importation are more those of apparel and clothing (HS 62 and HS 61), textiles (HS 63 and HS 60), fibres and synthetic filaments (HS 54 and HS 55), cotton (HS 52) and articles of leather (HS 42). All these sectors combined represent in total 48 per cent of all US collected duties, with an average rate of applied duties of 11 per cent. ${ }^{13}$ For the EU, on the other hand, it is more agricultural and food products which are the most highly taxed, and in particular the sectors of fruits and preserves (HS 8 and HS 20), meats (HS 2), sugar (HS 17), cereals (HS 10 and HS 19) and edible preparations (HS 21). All these agri-food sectors combined represent 18 per cent of European collected duties, with an average rate of applied duties of 12 per cent. ${ }^{14}$

${ }^{13}$ On entering the US market, the most highly taxed sectors represent $8,777,175,000 \$$ in collected duties and $82,602,488,000 \$$ worth of imports, for a total of collected duties of $18,297,016,000 \$$ in 2003 (Table 5).

${ }^{14}$ On entering the EU market, the most highly taxed sectors represent 2,611,438,000 Euros in collected duties and 21,971,352,000 Euros worth of imports, for a total of collected duties of $14,352,672,000$ Euros. 
Table 6: Main products contributing to the European and American import tax revenue

\begin{tabular}{|c|c|c|c|c|c|c|c|c|c|c|c|c|c|}
\hline HS & Description (short) & Import & \begin{tabular}{|l|} 
Collected \\
\end{tabular} & Import & Follectec & Rate & HS & Description (short) & Import & Collected & Import & Collected & Rate \\
\hline 2 digits & EU & $\begin{array}{c}1,000 € \\
{[1]}\end{array}$ & $\begin{array}{c}1,000 € \\
{[2]}\end{array}$ & Rank & Rank & 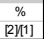 & 2 digits & USA & $\begin{array}{c}\$ 1,000 \\
{[1]} \\
{[1]}\end{array}$ & $\begin{array}{c}\$ 1,000 \\
{[2]}\end{array}$ & Rank & Rank & $\begin{array}{c}\% \\
{[2 n 1]} \\
{[2 n}\end{array}$ \\
\hline 87 & VEHOLESOTHERTHANRALLWAY ORTRAMWAY ROLLING-ST & $54,859,084$ & $2,099,374$ & 4 & 1 & 3.8 & 62 & ARTICLES OF APPAREL ANDQ_OTHING A COESSORES, NOT & $33,134,660$ & $3,684,548$ & 8 & 1 & 11.1 \\
\hline 62 & ARTICLES OF A PPAREL ANDQLOTHNG AOCESSORESS, NOT & $28,717,212$ & $1,376,221$ & 7 & 2 & 4.8 & 61 & ARTICLES OF APPAREL ANDQ OOTHING A OCESSORESE, KNTT & $29,683,020$ & $3,526,032$ & & 2 & 11.9 \\
\hline 85 & ELECTRCAL MA CHNERY ANDEQUPMENT ANDPARTS THERE & $117,310,352$ & $1,217,692$ & 3 & 3 & 1.0 & 87 & VEHICLES OTHERTHANRAILWAY ORTRAMWAY ROLLING-STO & $176,294,752$ & $2,434,323$ & 1 & 3 & 1.4 \\
\hline 61 & ARTIOLES OF APPAREL ANDQLOTHNG ACCESSORES, KNT & $21,185,276$ & 993,672 & 9 & 4 & 4.7 & 85 & ELECTRICAL MA CHINERY ANDEQUIPMENT ANDPARTS THERE & $156,239,584$ & $1,099,250$ & 3 & 4 & 0.7 \\
\hline 8 & EDBLLEFRUT ANDNUT;:PEEL OF CTRUS FRUTS ORME & $9,341,701$ & 972,010 & 22 & 5 & 10.4 & 84 & NUCE EARREA CTORS, BOILERS, MA CHINERY ANDMECHANICA & $169,231,584$ & 830,630 & 2 & 5 & 0.5 \\
\hline 29 & & $24,984,380$ & 601,700 & & 6 & 2.4 & 42 & ARTICLES OF LEATHER SA DDLERY ANDHARNESS; TRAVEL & $7,300,445$ & 740,641 & 25 & & 10.1 \\
\hline 64 & FOOTWEAR GATRES ANDTHELLKE; PARTS OF SUCHARTII & $10,668,847$ & 554,332 & 18 & 7 & 5.2 & 39 & PLASTICS ANDARTIOLES THEREOF & $22,717,410$ & 521,994 & 13 & 7 & 2.3 \\
\hline 84 & NUCLEARREACTORS, BOLLERS, MA CHINERY AND MEOHANCA & $123,650,952$ & 526,962 & 2 & 8 & 0.4 & 63 & OTHERMADE-UP TEXTLEARTIICES; SETS; WORNG_OTHNN & $6,669,288$ & 428,671 & 26 & 8 & 6.4 \\
\hline 2 & MEATANDEDBLEEMEAT OFFAL & $3,570,559$ & 519,735 & 37 & 9 & 14.6 & 94 & FUPNTURE; BEDONG, MA TTRESSES, MA TTRESS SUPPORTS, & $29,658,244$ & 280,943 & 10 & 9 & 0.9 \\
\hline 39 & PLASTIICS ANDARTICLES TIEREOF & $17,655,066$ & 435,420 & 12 & 10 & 2.5 & 29 & ORGANCCHEMICALS & $38,002,504$ & 267,652 & 6 & 10 & 0.7 \\
\hline 17 & SUGARSANDSUGARONFECTIONERY & $1,698,345$ & 359,786 & 63 & 11 & 21.2 & 69 & CERAMICPRODUCTS & $4,286,574$ & 241,170 & 34 & 11 & 5.6 \\
\hline 10 & GEREALS & $2,239,413$ & 316,318 & 55 & 12 & 14.1 & 71 & NA TURAL ORCU TURED PEARLS, PRECIOUS OR SEMI-PRECI & $28,151,200$ & 240,415 & 12 & 12 & 0.9 \\
\hline 3 & FISHAND CRUSTACEANS, MOLLUSCS ANDOTHERAQUATICI & $9,840,057$ & 284,603 & 19 & 13 & 2.9 & 27 & MINERAL FUELS, MNERAL OLLS ANDPRODUCTS OF THEIR & $145,355,168$ & 223,255 & 4 & 13 & 0.2 \\
\hline 20 & PREPARA TIONS OFVEGETABLES, FRUT, NUTS OROTHERP & $3,196,680$ & 241,541 & 45 & 14 & 7.6 & 90 & OPTICAL, PHOTOGRA PHIC, GNEMA TOGRA PHIC, MEA SURING, & $38,559,508$ & 215,451 & 5 & 14 & \\
\hline 90 & OPTICAL, PHOTOGRA PHIC, CINEMA TOGRA PHIC, MEA SURNNG, & $33,400,034$ & 239,583 & 5 & 15 & 0.7 & 73 & ARTICLES OF IRONORSTEEL & $15,133,229$ & 198,133 & 17 & 15 & 1.3 \\
\hline 76 & ALLMINUM ANDARTICLES THEREOF & $9,708,781$ & 216,391 & 20 & 16 & 22 & 82 & TOOLS, MPLLEMENTS, OULERY, SPOONS ANDFORKS, OF B & $5,158,576$ & 196,928 & 29 & 16 & \\
\hline 4 & DAIRY PRODUCE; BIRDS' EGGS; NA TURAL HONEY; EDIBLE & $1,314,544$ & 216,006 & 69 & 17 & 16.4 & 70 & GLASSAND GLASSWARE & $4,528,456$ & 180,340 & 32 & 17 & 4.0 \\
\hline 95 & TOYS, GAMESANDSPORTSREQUISTES; PARTS ANDACCES & $10,864,065$ & 199,347 & 17 & 18 & 1.8 & 91 & QLOOKSANDWATCHESANDPARTS THEREOF & $3,290,109$ & 177,554 & 40 & 18 & \\
\hline 63 & OTHERMADE-UP TEXTILEARTICEES; SETS; WORNCLOTHN & $5,057,014$ & 192,861 & 31 & 19 & 3.8 & 72 & IRONANDSTEEL & $10,217,271$ & 172,530 & 22 & 19 & 1.7 \\
\hline 42 & ARTIOLES OF LEA THER SADOLERY ANDHARNESS; TRAVEL & $5,855,862$ & 167,729 & 28 & 20 & 2.9 & 40 & RUBBERANDARTICLES THEREOF & $11,337,622$ & 165.593 & 20 & 20 & \\
\hline 16 & PREPARA TIONS OF MEAT, OF FISHOROF CRUSTA CEANS, M & $3,078,336$ & 167,481 & 47 & 21 & 5.4 & 20 & PREPARA TIONS OF VEGETABLES, FRUT, NUTS OROTHERP & $3,180,081$ & 150,157 & 41 & 21 & 4.7 \\
\hline 19 & PREPARA TIONS OF CEREALS, FLOUR STARCHORMLK; PA & 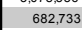 & 120,572 & 80 & 22 & 17.7 & 95 & TOYS, GAMES ANDSPORTS REQUSTIES; PARTS ANDACCES & $21,036,440$ & 133,235 & 14 & 22 & 0.6 \\
\hline 40 & RUBBERANDARTILLES THEREOF & $\begin{aligned} 9,296,678 \\
\end{aligned}$ & 112,222 & 23 & 23 & 12 & 52 & 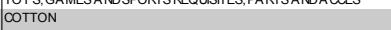 & $\begin{array}{r}2,1,300,474 \\
1,413\end{array}$ & 127,731 & 55 & 23 & 7.0 \\
\hline 73 & ARTICLES OF IRONORSTEEL & $11,910,994$ & & 16 & 24 & 0.9 & 54 & MAN-MADEFILAMENTS & & 112,280 & 54 & 24 & \\
\hline 54 & MANMADEFLAMENTS & $2,877,846$ & 89,339 & 50 & 25 & 3.1 & 4 & DAIRY PRODUCE; BIPDS' EGGS; NA TURAL HONEY; EDIBLE & $\begin{array}{l}1,0350,306 \\
1,306\end{array}$ & 105,389 & 64 & 25 & 7.8 \\
\hline 38 & MISCELLANEOUS CHEMICAL PRODUCT & & & & & & & & & & & & \\
\hline 94 & FURNTURE; BEDDNG, MA TTRESSES, M & $\begin{array}{ll}0,10,811,876 \\
1610\end{array}$ & 87,023 & 13 & 27 & 0.5 & 96 & MISOELLANEOUS MANUFACTUREDARTIOES & $2,898,887$ & 97,678 & 42 & 27 & 3.4 \\
\hline 32 & TAMNING ORDY ENG E & $3,096,9$ & 86,688 & & 28 & & 83 & MISCELLANEOUSARTICLES OF BASEMET & $5,358,251$ & 94,316 & & 28 & \\
\hline 21 & MISCELLANEOUS EDBBLEPREPARA TIOI & $1,241,921$ & 81,476 & 70 & 29 & 6.6 & 32 & TANNNG ORDY EING EXTRA CTS; TANNNS AND THERRDERI & 2,468,855 & 84,033 & 48 & 29 & 3.4 \\
\hline 22 & BEVERA GES, SPRRTS ANDVINEGAR & 3.527. & & 38 & 30 & 2.3 & 60 & & $1,025,506$ & 83,416 & 76 & 30 & 8.1 \\
\hline 82 & 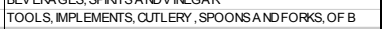 & $\begin{array}{l}3,02,745 \\
3,991,088\end{array}$ & 79,984 & 34 & 31 & $\begin{array}{l}2.0 \\
2.0\end{array}$ & 38 & MISCELLANEOUS CHEMICAL PRODUCTS & 5,320,942 & 77,855 & 28 & 31 & 1.5 \\
\hline & IRONANDSTEEL & $13,887,896$ & 78,822 & & & & 55 & & & 73,856 & 71 & 32 & 6.5 \\
\hline 70 & GLASSANDGLASSWARE & 3,623 & 77,8312] & 36 & 33 & 2.1 & 65 & 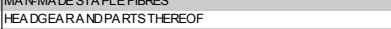 & 1,357 & 73,683 & 63 & 33 & 5.4 \\
\hline & EDIBLEV & & & & & & 76 & & & 63,502 & 23 & 34 & 0.7 \\
\hline 28 & INORGANCOFMMICALS: ORGANCORINORGANIC COMPOUND & $\begin{array}{l}2,155,484 \\
5,129,534\end{array}$ & 75,658 & 30 & 35 & $\frac{2.8}{1.5}$ & 24 & 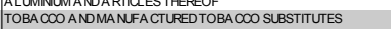 & $1,297,765$ & 63,167 & 66 & 35 & 4.9 \\
\hline 27 & MINERAL FUELS, MINERAL OILSANDPROD & 144,610 & & & & 0.1 & 16 & & & 61,949 & 44 & 36 & 2.2 \\
\hline 15 & ANMAL ORVEGETABLEFA TSAND OLLSAND THERRQEAVA & $2,384,454$ & 71,159 & 53 & 37 & 3.0 & 21 & MISCELLANEOUS EDIBLEPREPARA TIONS & $1,789,370$ & 60,262 & 56 & 37 & 3.4 \\
\hline 52 & COTTON & & 70,681 & 42 & 38 & 2.1 & 67 & (1) & & 59,958 & 69 & 38 & 4.9 \\
\hline 37 & PHOTOGRA PHICORCINEMA & 1,550 & 67,119 & 65 & 39 & 4.3 & 37 & & & 56,532 & 51 & 39 & 2.6 \\
\hline \multirow[t]{4}{*}{91} & Q.OCKS ANDWATCHESA & $3,817,260$ & 58,698 & 35 & 40 & 1.5 & 92 & ESOF SUCH & $1,362,510$ & 51,478 & 62 & 40 & 3.8 \\
\hline & & $738,805,847$ & $13,486,411$ & & & 1.8 & & & $20,437,083$ & & & & 1.7 \\
\hline & & $933,349,386$ & $14,352,672$ & & & 1.5 & & & $1,227,007,745$ & $18,297,016$ & & & 1.5 \\
\hline & Selection in & & & & & & & & & & & & \\
\hline
\end{tabular}

Selection in grey for rate of collected $>5$ per cent

Sources : SAD (Eurostat); TARIC (DG Taxud); USITC

\section{SUMMARY AND CONCLUSIONS}

Relating the collected customs duty to the value of imports enables to estimate a rate of applied duty that takes into account all the pricing components and their utilisation. This AVE of the duty actually applied is not without bias on the measurement of protection, because the importance of imports and collected duties remain dependent upon the level of taxes and other non-tariff barriers, such as quotas. Nevertheless, processing collected duties has the advantage of revealing customs duties' actual level of levies. It emerges from this analysis that even if the EU and US rate of applied duties is equivalent (1.5 per cent), the US taxes LDCs and developing countries much more than the EU. For the US market the sectors that are the most highly taxed after import are primarily textiles, apparel and clothing, cotton and articles of leather, whereas for 
the EU it is more agricultural and food products (fruits and preserves, meats, sugars and cereals). This assessment is important in relation to current WTO discussions, for it shows that concessions regarding agricultural market access cannot be dissociated from those concerning industrial products, as protection in both agriculture and industry persists for the poorest countries. 


\section{REFERENCES}

Bchir H., S. Jean and D. Laborde (2005), 'Binding Overhang and Tariff-Cutting Formulas', CEPII Working Paper No 2005-18.

Bourcieu E. (2004), 'Comparaison des Régimes Tarifaires Européen et Américain selon

l'Approche Appliquée par E. Gresser au Cas Américain', Note de dossier, European Commission.

CEC (2005), 'Rules of Origin in Preferential Trading Agreements - Orientations for the Future', COM (2005) 100 Final.

Brenton P. and M. Manchin (2002), 'Making EU Trade Agreements Work: the Role of Rules of Origin', Centre for European Policy Studies Working Document No. 183.

Candau F. and S. Jean (2005), 'What are EU Trade Preferences Worth for Sub-Saharan Africa and other Developing Countries?', CEPII working papers No 2005-19.

Curran L., G. Frontini and L. Nilsson (2006), 'The Potential for Preference Erosion on the

EU Market', Ninth Annual Conference on Global Economic Analysis, Addis Ababa, Ethiopia.

Eurostat (2003), 'Statistiques sur les Echanges de Biens. Guide de l'Utilisateur', (Luxembourg: Office for Official Publications of the European Communities).

Gallezot J. and J.-C. Bureau (2005), 'The Trade Effects of the EU's Everything but Arms Initiative', Mimeo.

Gallezot J. and J.-C. Bureau (2004), 'Preferential Trading Arrangements in Agricultural and Food Markets: The Case of the European Union and the United States', COM/AGR/TD/WP/(2004)/12 (Paris: OECD).

Gallezot J. (2003), 'Real Access to the EU's Agricultural Market', DG Trade Seminar, Agriculture, Trade and Development, Thursday, July 24th, Brussels.

Gresser E. (2002a), 'America's Hidden Tax on the Poor. The case for Reforming U.S. Tariff Policy' (Washington DC: Progressive Policy Institute). 
Gresser E. (2002b), 'Toughest on the Poor, Tariffs, Taxes, and the Single Mom', (Washington DC: Progressive Policy Institute).

OECD (2005), 'Trade Preference Erosion: Potential Economic Impacts', TD/TC/WP(2004)30/REV1 (Paris).

USITC (2004), 'Value of U.S. Import for Consumption, Duties Collected, and Ratio of Duties to Values 1891 - 2003' (Washington DC). 


\section{APPENDIX}

\section{Methodology for the analysis of collected duties}

Declarations made by importing companies form the basis of European trade statistics, and records for that operation are based on customs declarations using the Single Administrative Document (SAD). This declaration includes all of the information which constitutes the basis of EU external trade statistics (value, quantity, origin, supplementary units). These elements are the object of a statistical treatment by the National Statistical Offices. They are transmitted to Eurostat which constructs the official European external trade database (COMEXT). At this level, the operations done by Eurostat consist in harmonising the data in accordance to the different import regimes. ${ }^{15}$ The COMEXT database concerns only extra-EU imports as it is also the case for all the figures shown in the present paper. In addition, only the 15 former Member States of the European Union are under study as the statistics used are from the year 2003, before EU enlargement.

Complementary to this information, the SAD form specifies (box 36) the import regime chosen by the importer (MFN or specific preferential treatment). This regime corresponds to the one required by the importer under its sole responsibility. It does not always correspond to the regime effectively applied by the customs administration as the goods in question, i.e. their origin, may not allow for the regime requested. Systems are in place to correct such type of mistakes by the importer.

The Member States do not transmit detailed information on type and origin of the products which enter the European market over their national borders. Only the total amount of duties collected is accessible for the public as it corresponds to a specific part of the transfers to the European budget by the Member States (25 per cent are not

\footnotetext{
${ }^{15}$ These regimes allow distinguishing between inward for or after processing trade, outward for or after processing trade, and normal imports (Eurostat, 2003).
} 
transferred as a compensation for administrative costs). At EU level, there is no more information than the total amount of money perceived from each Member State.

Utilising the TARIC database allows to estimate the collected duty's amount according to the good's regime and value. The corresponding forms of taxation (ad-valorem, specific, complex, additional or suspensive) are then applied according to the origin of the product, and the total volume of the duty collected by the EU is matched to the amount levied by all the Member States. 
Table 7 (continuation of Table 5): EU and US collected duties for the 50 to 100

contributing countries in 2003

\begin{tabular}{|c|c|c|c|c|c|c|c|c|c|c|c|c|c|}
\hline EUimport & Import & Collected & Import & Collected & GNI & Rate & US import & Import & Collected & Import & Collected & GNI & Rate \\
\hline \multirow[t]{2}{*}{ from countries } & $1,000 €$ & $1,000 €$ & Rank & Rank & Rank & $\%$ & from countries & $\$ 1,000$ & $\$ 1,000$ & Rank & Rank & Rank & \\
\hline & [1] & [2] & & & & [2\1] & & [1] & [2] & & & & [2y[1] \\
\hline Israel & $7,143,909$ & 29,837 & 28 & 51 & 28 & 0.4 & Mongolia & 183,420 & 28,832 & 103 & 51 & 189 & 15.7 \\
\hline Ivory Coast & $2,511,224$ & 28,521 & 51 & 52 & 171 & 1.1 & Chile & $3,729,447$ & 28,680 & 41 & 52 & 86 & 0.8 \\
\hline Slovenia & $7,139,310$ & 28,269 & 29 & 53 & 62 & 0.4 & Ireland & $25,763,320$ & 27,463 & 10 & 53 & 16 & 0.1 \\
\hline Yugoslavia & $1,246,972$ & 27,141 & 63 & 54 & 138 & 2.2 & Finland & $3,594,213$ & 27,094 & 43 & 54 & 12 & 0.8 \\
\hline Saudi Arabia & $11,796,464$ & 26,975 & 20 & 55 & 68 & 0.2 & Bulgaria & 432,447 & 27,060 & 77 & 55 & 127 & 6.3 \\
\hline Fiji & 108,424 & 26,519 & 133 & 56 & 118 & 24.5 & South Africa & $4,857,622$ & 25,563 & 33 & 56 & 111 & 0.5 \\
\hline Jamaica & 459,424 & 24,428 & 90 & 57 & 110 & 5.3 & Romania & 670,624 & 25,560 & 71 & 57 & 124 & 3.8 \\
\hline Yugoslav Rep.of Maced & 632,915 & 24,290 & 79 & 58 & 131 & 3.8 & Slovakia & 980,247 & 23,720 & 66 & 58 & 88 & 2.4 \\
\hline Cuba & 312,260 & 23,203 & 104 & 59 & 120 & 7.4 & Oman & 592,809 & 22,658 & 74 & 59 & 69 & 3.8 \\
\hline Liechtenstein & 952,571 & 23,097 & 70 & 60 & 4 & 2.4 & Poland & $1,294,878$ & 22,631 & 62 & 60 & 80 & 1.7 \\
\hline Sw aziland & 128,444 & 22,162 & 128 & 61 & 142 & 17.3 & Mauritius & 295,884 & 22,476 & 92 & 61 & 95 & 7.6 \\
\hline Dominican Republic & 329,490 & 19,910 & 101 & 62 & 114 & 6.0 & Hungary & $2,675,582$ & 22,196 & 49 & 62 & 77 & 0.8 \\
\hline Cambodia (Kampuchea) & 491,537 & 19,395 & 86 & 63 & 204 & 3.9 & Nepal & 171,238 & 21,300 & 107 & 63 & 213 & 12.4 \\
\hline Libya & $10,325,429$ & 19,196 & 24 & 64 & 79 & 0.2 & Norw ay & $5,030,323$ & 19,619 & 32 & 64 & 2 & 0.4 \\
\hline Cyprus & 733,448 & 18,730 & 75 & 65 & 50 & 2.6 & Greece & 600,913 & 16,396 & 73 & 65 & 57 & 2.7 \\
\hline Egypt & $3,077,862$ & 18,270 & 44 & 66 & 135 & 0.6 & Qatar & 331,576 & 15,979 & 90 & 66 & 53 & 4.8 \\
\hline Lithuania & $2,925,561$ & 17,873 & 46 & 67 & 98 & 0.6 & Ecuador & $2,424,197$ & 14,466 & 51 & 67 & 134 & 0.6 \\
\hline Belize & 79,133 & 16,355 & 141 & 68 & 105 & 20.7 & Morocco & 393,315 & 14,320 & 83 & 68 & 143 & 3.6 \\
\hline Namibia & 458,998 & 14,797 & 92 & 69 & 132 & 3.2 & Costa Rica & $3,315,552$ & 13,987 & 45 & 69 & 89 & 0.4 \\
\hline Estonia & $3,035,539$ & 11,407 & 45 & 70 & 82 & 0.4 & Israel & $12,750,957$ & 13,811 & 18 & 70 & 28 & 0.1 \\
\hline Malaw i & 187,006 & 11,403 & 120 & 71 & 221 & 6.1 & Fiji & 172,165 & 13,523 & 106 & 71 & 118 & 7.9 \\
\hline Venezuela & $1,719,223$ & 10,097 & 56 & 72 & 93 & 0.6 & Ukraine & 278,601 & 13,393 & 93 & 72 & 163 & 4.8 \\
\hline Zambia & 143,290 & 10,053 & 125 & 73 & 198 & 7.0 & Czech rep. & $1,385,240$ & 12,031 & 60 & 73 & 75 & 0.9 \\
\hline Belarus & $1,029,244$ & 9,485 & 68 & 74 & 140 & 0.9 & Peru & $2,391,173$ & 10,723 & 52 & 74 & 119 & 0.4 \\
\hline Botsw ana & $1,506,686$ & 9,325 & 61 & 75 & 109 & 0.6 & Maldives & 94,072 & 10,284 & 115 & 75 & 115 & 10.9 \\
\hline Trinidad and Tobago & 450,095 & 8,388 & 94 & 76 & 71 & 1.9 & Kuw ait & $2,125,244$ & 10,102 & 54 & 76 & 27 & 0.5 \\
\hline Zimbabw e & 484,642 & 8,130 & 87 & 77 & 167 & 1.7 & Lithuania & 346,972 & 10,043 & 88 & 77 & 98 & 2.9 \\
\hline Latvia & $1,950,731$ & 7,920 & 55 & 78 & 97 & 0.4 & Uruguay & 236,243 & 9,367 & 98 & 78 & 84 & 4.0 \\
\hline Iran & $6,829,692$ & 7,490 & 30 & 79 & 129 & 0.1 & Haiti & 331,430 & 8,904 & 91 & 79 & 187 & 2.7 \\
\hline Algeria & $10,971,411$ & 7,445 & 22 & 80 & 130 & 0.1 & Turkmenistan & 79,554 & 8,446 & 121 & 80 & 159 & 10.6 \\
\hline Kazakhstan & $3,436,792$ & 7,055 & 42 & 81 & 133 & 0.2 & Iraq & $3,762,774$ & 8,305 & 40 & 81 & 151 & 0.2 \\
\hline Moldova & 247,720 & 6,866 & 111 & 82 & 183 & 2.8 & Slovenia & 476,012 & 7,592 & 76 & 82 & 62 & 1.6 \\
\hline Malta & 851,039 & 6,100 & 73 & 83 & 63 & 0.7 & Kazakhstan & 396,836 & 7,073 & 81 & 83 & 133 & 1.8 \\
\hline St.Lucia & 23,349 & 6,087 & 158 & 84 & 96 & 26.1 & Belarus & 218,206 & 6,450 & 99 & 84 & 140 & 3.0 \\
\hline Peru & $2,211,099$ & 5,957 & 54 & 85 & 119 & 0.3 & Yugoslav Rep. & 61,276 & 6,448 & 126 & 85 & 131 & 10.5 \\
\hline Kenya & 786,110 & 5,477 & 74 & 86 & 197 & 0.7 & Algeria & $4,433,566$ & 6,429 & 34 & 86 & 130 & 0.1 \\
\hline Honduras & 264,439 & 5,195 & 109 & 87 & 154 & 2.0 & Tunisia & 98,443 & 6,341 & 114 & 87 & 122 & 6.4 \\
\hline Bahrain & 309,844 & 5,136 & 105 & 88 & 55 & 1.7 & Syria & 241,437 & 6,065 & 97 & 88 & 146 & 2.5 \\
\hline Barbados & 38,110 & 4,656 & 155 & 89 & 66 & 12.2 & Uzbekistan & 83,593 & 6,044 & 118 & 89 & 186 & 7.2 \\
\hline Netherlands Antilles & 102,524 & 4,394 & 135 & 90 & 51 & 4.3 & Latvia & 395,305 & 5,336 & 82 & 90 & 97 & 1.3 \\
\hline Sudan & 202,654 & 4,348 & 117 & 91 & 192 & 2.1 & Liechtenstein & 261,867 & 5,019 & 94 & 91 & 4 & 1.9 \\
\hline StVincent & 52,789 & 3,951 & 149 & 92 & 106 & 7.5 & Moldova & 39,491 & 4,821 & 134 & 92 & 183 & 12.2 \\
\hline Paraguay & 287,686 & 3,890 & 107 & 93 & 144 & 1.4 & Malta & 368,854 & 4,735 & 87 & 93 & 63 & 1.3 \\
\hline Tanzania & 608,037 & 3,446 & 80 & 94 & 202 & 0.6 & Lesotho & 393,056 & 3,592 & 84 & 94 & 177 & 0.9 \\
\hline Uzbekistan & 500,600 & 3,331 & 83 & 95 & 186 & 0.7 & Sw aziland & 162,033 & 3,213 & 110 & 95 & 142 & 2.0 \\
\hline Laos & 120,032 & 3,285 & 130 & 96 & 199 & 2.7 & Jordan & 673,290 & 2,957 & 70 & 96 & 126 & 0.4 \\
\hline Kuw ait & $1,692,027$ & 3,088 & 58 & 97 & 27 & 0.2 & Zimbabwe e & 66,570 & 2,923 & 123 & 97 & 167 & 4.4 \\
\hline Gibraltar & 131,404 & 2,964 & 127 & 98 & 46 & 2.3 & Estonia & 170,500 & 2,843 & 108 & 98 & 82 & 1.7 \\
\hline Aruba & 105,848 & 2,868 & 134 & 99 & 58 & 2.7 & Aruba & 842,201 & 2,345 & 68 & 99 & 58 & 0.3 \\
\hline Guatemala & 250,883 & 2,626 & 110 & 100 & 128 & 1.0 & Kenya & 248,037 & 2,311 & 96 & 100 & 197 & 0.9 \\
\hline Total Selection [1] & $91,383,920$ & 620,831 & & & & & Total Selection [1] & $90,922,605$ & 641,469 & & & & \\
\hline Total EU2003 [2] & $933,349,386$ & $14,352,672$ & & & & & Total USA 2003 [2] & $1,227,007,745$ & $18,297,016$ & & & & \\
\hline Selection in \% ([1]Y2]) & 9.8 & 4.3 & & & & & Selection in \% ([1y[2]) & 7.4 & 3.5 & & & & \\
\hline
\end{tabular}

Countries selection in grey for GNI rank $>100$ and rate of collected $>5$ per cent

Sources : SAD (Eurostat), TARIC (DG Taxud), USITC, UN Statistics Division 